\title{
PIJAT KENDIKU: ANTARA KEARIFAN LOKAL DAN KEKECEWAAN TERHADAP PENGOBATAN MEDIS
}

\author{
Agustin Putri Wulansari (1), Nur Hadi ${ }^{(2)}$, Joan Hesti Gita Purwasih ${ }^{\left(3^{*}\right)}$ \\ 123 Faculty of Social Sciences, Universitas Negeri Malang, East Java, Indonesia.
}

\section{ARTICLE INFORMATION

$\begin{array}{ll}\text { Submitted } & : 26^{\text {th }} \text { Nopember } 2020 \\ \text { Review } & : 02^{\text {nd }} \text { Nopember } 2021 \\ \text { Accepted } & : 26^{\text {th }} \text { Nopember } 2021 \\ \text { Published } & : 18^{\text {th }} \text { December } 2021 \\ \text { Available Online : December } 2021\end{array}$

\section{KEYWORDS}

Traditional; Existence; Local Wisdom; Pijat Kendiku; Medical treatment

\section{CORRESPONDENCE}

*E-mail: joan.hesti.fis@um.ac.id

\begin{abstract}
A B S T R A C T
The current era of modernization has entered every line of human life, including the medical world. However, not all people can reach medical treatment even though the government has provided health service facilities. In line with this, traditional alternative medicine such as massage is still popular to cure ailments among the public. The author tries to raise the reasons why people prefer traditional medicine over medical treatment. This study used qualitative ethnographic methods with data collection techniques that are interviews and observations. The result of the research serves as documentation of cultural features in the health sector that is still developing in society. As an analytical technique, the author used James $C$. Young's health anthropology perspective. The data analyses used are data collection, data reduction, and data presentation in descriptions. This research showed that people prefer massage as a healing method for many reasons, such as having more affordable prices, being unprepared for the risk of medical treatment, feeling disappointment with medical treatment that does not work, and trusting in personalistic illness.
\end{abstract}

\section{A. PEndahuluan}

$\mathrm{S}$ ehat merupakan aset yang berharga bagi semua orang. Seseorang dapat dikatakan sehat saat tubuh berada dalam keadaan yang sempurna baik secara fisik, mental dan sosial serta bebas dari penyakit dan kondisi yang melemahkan tubuh (WHO dalam Whi, n.d.). Sebaliknya, sakit adalah keadaan tubuh saat berada dalam kondisi yang kurang baik. Adanya rasa sakit ini timbul dari penyakit yang diakibatkan oleh genetika, lingkungan, pola makan dan gaya hidup (Womack, 2010).

Ketika tubuh berada dalam kondisi sakit, seseorang akan berusaha mencari penyembuhan. Penyembuhan atau pengobatan dilakukan untuk mengembalikan kondisi tubuh seperti sedia kala. Umumnya, pengobatan dilakukan oleh orang yang ahli seperti dokter. Pemilihan penyembuhan dengan pergi ke dukun sudah tidak lagi seperti dahulu ketika dukun dipilih untuk pertolongan pertama pengobatan.

Seiring berkembangnya zaman, ilmu pengetahuan dan teknologi sudah kian maju dan merambah di berbagai lini kehidupan manusia. Bidang kesehatan medis tak luput dari perkembangan teknologi, dibuktikan dengan adanya alat-alat kesehatan yang kian canggih. Teknologi tersebut diharapkan mampu membantu manusia dalam mengembangkan pelayanan dan obat-obat baru agar kualitas hidup menjadi lebih baik (Tjandrawinata, 2016).

Salah satu fungsi pemerintah yaitu menyediakan kebutuhan masyarakat dalam hal pelayanan kesehatan. Pelayanan kesehatan harus terus 
diupayakan dan ditingkatkan sebab menyangkut dengan hak asasi manusia (Prakoso, 2015). Akan tetapi pada kenyataannya, meskipun pelayanan kesehatan sudah difasilitasi dan peningkatan kenaikan iuran tarif dilakukan, kondisi tersebut tidak diimbangi dengan peningkatan pelayanan kesehatan (Rarasati, 2018).

Kondisi tersebut tercermin pada program BPJS, masih banyak persoalan mengenai kurang meratanya pelayanan kesehatan masyarakat. Terlebih lagi dijumpai diskriminasi terhadap pasien pada pelayanan kesehatan. Ketika seseorang mampu membayar biaya perawatan, maka ia akan mendapatkan pelayanan kesehatan yang optimal. Sementara itu, orang yang tidak memiliki biaya sering tidak mendapat perlakuan baik. Mereka bahkan ditolak berobat di suatu rumah sakit (Ticoalu, 2013).

Dasar penolakan tersebut dikarenakan profit oriented dan beban biaya operasional rumah sakit yang tinggi. Oleh karena itu, rumah sakit akan melayani pasien yang memberikan jaminan pembiayaan. Selain itu, belum efektifnya pelayanan kesehatan pada masyarakat miskin melalui BPJS ini kemudian membuat masyarakat berfikir ulang untuk melakukan pengobatan medis (Putri, 2014).

Masalah utama dalam pemerataan layanan kesehatan disebabkan adanya isu kemiskinan struktural di Indonesia. Biaya pengobatan dalam hal ini menjadi faktor penting seseorang dalam memilih metode pengobatan. Selain itu pemerataan akses layanan kesehatan juga menjadi suatu masalah tersendiri (Ticoalu, 2013). Sejalan dengan hal itu, maka pilihan metode penyembuhan lain seperti pengobatan alternatif masih banyak digunakan oleh masyarakat.

Penyembuhan alternatif adalah penyembuhan yang dilakukan secara non medis dan sebagian besar merupakan pengobatan tradisional (Ardani, 2013). Pengobatan tradisional masih tetap eksis dipercaya dan digunakan oleh masyarakat untuk menyembuhkan suatu penyakit (Ardani, 2013). Pada masyarakat Jawa, cara dan obat-obat tradisional untuk mengatasi penyakit masih digunakan dalam kehidupan seharihari. masyarakat percaya bahwa pengobatan alternatif merupakan tradisi dari nenek moyang. Selain itu, obat tradisional ini masih banyak digunakan karena murah, mudah didapat, dan manjur (Triratnawati, 2010).

Pengobatan tradisional memiliki beberapa nilai lebih bila dibandingkan dengan pengobatan medis. Pertama, pengobatan tradisional menggunakan ramuan obat-obat herbal yang memiliki efek samping lebih kecil daripada obat-obatan kimia dengan dosis tinggi. Kedua, pengobatan tradisional bersifat khas dan berbeda antar satu daerah dengan daerah lainnya
(Triratnawati, 2010). Hal ini akibat dari proses adaptasi masyarakat terhadap lingkungan tempat tinggal, kondisi sosial dan budaya yang kemudian memengaruhi kesehatan cara penyembuhan penyakit. Berbeda halnya dengan pengobatan medis yang bersifat menyamaratakan pengobatan pada pasien tanpa membedakan kondisi sosial dan pola perilaku yang berbeda (Womack, 2010).

Metode pengobatan tradisional sangat beragam karena merupakan salah satu dari wujud kebudayaan manusia intangible (tidak terlihat) yang berupa ide atau gagasan (Honigmann dalam Moeis, 2009). Ide dan gagasan ini dipengaruhi oleh berbagai kondisi seperti halnya lingkungan tempat tinggal, sehingga wujud kebudayaan akan tercermin beragam di setiap daerah. Keberagaman ini terlihat dari banyaknya jenis pengobatan tradisional di Indonesia seperti jamu, akupuntur, pijat dan lain sebagainya (Suharyanto, 2015).

Pijat (massage) merupakan sebuah metode penyembuhan tradisional dengan cara memberikan tekanan, gerakan maupun getaran yang dilakukan baik secara manual maupun menggunakan alat mekanik pada tubuh (Ayunita, 2016). Pijat dipercaya dapat menurunkan rasa nyeri pada tubuh melalui relaksasi otot sehingga dapat mengendurkan otot-otot yang tegang dan relaksasi pikiran. Sebuah penelitian yang dilakukan pada tahun 2012 menyebutkan bahwa pijat mampu mengelola gangguan mood atau perasaan seseorang (Sliz et al., 2012). Selain itu, terapi pijat ini dimaksudkan untuk mengharmonisasikan fisik dan psikis seseorang sehingga dapat tercipta keseimbangan dalam tubuh (Moordiningsih, 2009).

Pijat biasanya dilakukan oleh seorang yang ahli memijat, atau sering disebut dukun pijat. Pada masyarakat Jawa, istilah 'dukun' diartikan sebagai orang yang mengobati, menolong orang sakit atau memberikan jampi-jampi untuk kesembuhan (Huda, 2015). Pada umumnya masyarakat juga percaya bahwa dukun pijat mampu memahami sumber-sumber penyakit pada pasien yang berasal dari kondisi biologis, psikologis, maupun sosial pasien. Adapun metode penyembuhan yang dilakukan oleh seorang dukun pijat pada umumnya tidak hanya keterampilan dalam memijat, tetapi ditunjang pula oleh penggunaan obat-obat herbal (Womack, 2010).

Praktik pijat pada masyarakat dapat dijumpai pada klinik, rumah, ataupun panti pijat. Klinik atau panti pijat merupakan suatu tempat yang menyediakan jasa pijat, pasien bisa langsung datang sewaktu-waktu ke tempat tersebut. Selain itu, juga terdapat 'dukun pijat panggilan' yang bersedia untuk datang ke rumah pasien sesuai dengan waktu yang telah disepakati 
sebelumnya. Praktik ini masih banyak dijumpai pada masyarakat.

Di Desa Cengkok Kecamatan Ngronggot Kabupaten Nganjuk terdapat sebuah rumah panti pijat bernama Kendiku. Adapun yang membuat masyarakat tertarik dengan panti pijat ini yakni karena metode penyembuhan yang ditawarkan memiliki perbedaan dengan pijat pada umumnya. Perbedaan itu antara lain yakni durasi pijat tidak lebih dari 15 menit, penggunaan pil dan jamu herbal, serta pemberian pantanganpantangan makanan kepada pasiennya Hampir setiap hari panti tersebut penuh dengan pasien dari berbagai daerah seperti Pati, Cepu, Surabaya, Jombang dan masih banyak lagi. Panti pijat Kendiku mudah dijumpai dari jalan utama seperti yang peneliti tunjukkan pada gambar 1.

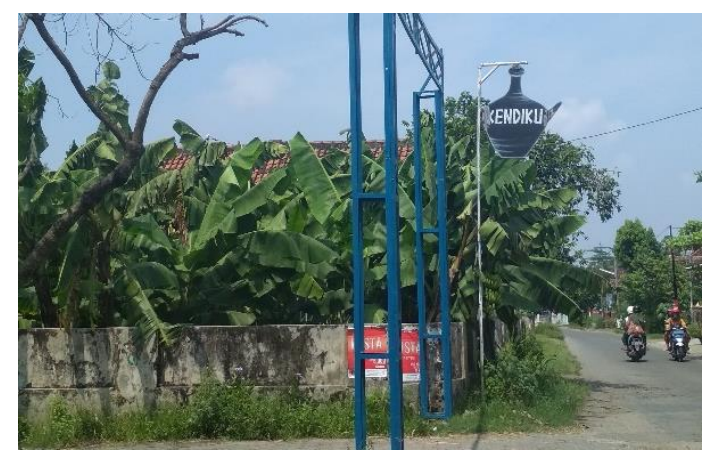

Gambar 1.

Papan nama Panti Pijat Kendiku dari jalan utama. Sumber : Dokumentasi Pribadi

Berdasarkan paparan yang sudah dikemukakan, peneliti menggali alasan masyarakat dalam memilih pengobatan pijat tradisional daripada pengobatan medis modern. Penelitian serupa mengenai pemilihan metode penyembuhan pernah dilakukan, namun berfokus pada pijat sebagai pengobatan tradisional dan hasil budaya atau kearifan lokal masyarakat (Nuari, 2016; Setyoningsih \& Artaria, 2016). Selain itu, penelitian lain juga lebih menjelaskan preferensi individu terhadap pengobatan tradisional di Indonesia dengan penyajian data secara kuantitatif (Jennifer \& Saptutyningsih, 2015; S. Supardi, S. Jamal, 2003). Hasil penelitian tersebut menunjukkan bahwa pengobatan alternatif lebih dipilih masyarakat karena beberapa faktor antara lain usia, tempat tinggal, keberadaan pos obat, pendidikan, tingkat ekonomi, penyembuhan secara medis yang tidak membuahkan hasil, serta pengobatan alternatif yang dinilai dapat menyembuhkan penyakit bersifat personalistik.

Pada penelitian ini, peneliti menunjukkan bahwa eksistensi pengobatan tradisional selain dimaknai sebagai budaya atau kearifan lokal juga berkaitan dengan preferensi individu terkait pilihan metode penyembuhan. Tingkah laku manusia dalam mengatasi permasalahan kesehatan dan penyakit menjadi sudut pandang yang digunakan secara tajam untuk menunjukkan relevansi di antara keduanya secara mendalam.

\section{B. METODE PENELITIAN}

$\mathrm{P}$ enelitian ini menggunakan metode penelitian kualitatif dengan pendekatan etnografi. Pendekatan etnografi dipilih untuk menafsirkan serta memahami pola-pola perilaku, nilai, dan kepercayaan masyarakat dari berbagai kelompok budaya (Cresswell, 2007). Penelitian ini dilakukan di Desa Cengkok Kecamatan Ngronggot Kabupaten Nganjuk. Subyek dalam penelitian ini adalah pasien yang datang berobat di panti pijat Kendiku. Teknik pengumpulan data penelitian yakni menggunakan wawancara dan observasi untuk mendapatkan data yang mendalam. Keabsahan data dilakukan dengan triangulasi sumber. Sedangkan teknik analisis data dalam penelitian ini adalah pengumpulan data, reduksi data, dan penyajian data dalam deskripsi yang utuh. Penelitian ini mengungkapkan tentang konsep pijat urat Kendiku, serta menjelaskan penyebab masyarakat tertarik menggunakan jasa pijat Kendiku daripada alternatif pengobatan yang lainnya.

\section{HASIL DAN PEMBAHASAN}

\section{Mengenal Pijat Urat Kendiku}

$\mathrm{K}$ abupaten Nganjuk, Jawa Timur, memiliki sebuah panti pijat bernama Kendiku. Rumah panti pijat ini tepatnya berada di Desa Cengkok Kecamatan Ngronggot. Daerah Ngronggot sendiri merupakan daerah pedesaan yang sebagian besar terdiri dari area persawahan dengan warga mayoritas adalah petani dan pedagang. Panti Kendiku berada pada area padat penduduk dengan jarak tempuh kurang lebih 10 menit dari pusat kegiatan masyarakat di Kecamatan Ngronggot.

Pada mulanya, praktik pijat Kendiku dibuka pada tahun 1990 oleh generasi pertama keluarga Bapak Haji Jono. Awalnya, kemampuan pijat urat Kendiku ini tidak didapatkan melalui pelatihan-pelatihan. Ketrampilan pijat ini didapatkan keluarga Bapak Haji Jono dari warisan kebudayaan dan keterampilan budaya sekitar. Berawal dari keinginan untuk membantu masyarakat sekitar, rumah panti pijat ini kemudian dibuka sebagai panti pijat untuk menyembuhkan berbagai penyakit warga melalui metode pijat urat. Jasa beliau kemudian 
tersebar dari mulut ke mulut hingga ke antar daerah lainnya. Barulah pada tahun 2005, Pijat Kendiku ini kian booming dan terkenal berkat adanya teknologi media massa.

Kemampuan pijat di panti hingga kini sudah mencapai generasi kedua. Panti pijat ini kemudian dikelola oleh generasi penerus keluarga untuk dilestarikan sehingga diharapkan dapat tetap bermanfaat untuk orang lain. Hingga kini, rumah panti pijat Kendiku dijalankan dan dikelola oleh Bapak Purnomo (putra Bapak Haji Jono) dan istrinya. Pelanggan pengguna jasa pijat Kendiku saat ini tersebar hingga ke daerah Jombang, Lamongan, Pati, Solo hingga Singapura dan Pakistan.

Pelanggan bisa datang ke panti pijat di daerah Cengkok ini kapanpun tanpa membuat janji terlebih dahulu. Begitu tiba di panti pijat ini, pasien akan disediakan kursi dengan jumlah banyak yang digunakan untuk mengantri. Antrian dapat lebih panjang dan lama di hari libur, sebab masyarakat biasanya dapat mendampingi keluarganya mencari kesembuhan saat libur bekerja. Rumah panti pijat Kendiku ini beroperasi setiap hari kecuali hari Jumat yang hanya buka setengah hari.

Rumah panti pijat Kendiku ini memiliki dua buah kamar yang digunakan untuk memijat pasien. Dukun pijat hanya Bapak Purnomo seorang selaku pemilik panti pijat. Beliau secara bergantian memijat pasien dari kamar satu ke kamar lainnya. Pasien yang sudah selesai dipijat kemudian akan digantikan oleh pasien dari antrian berikutnya.

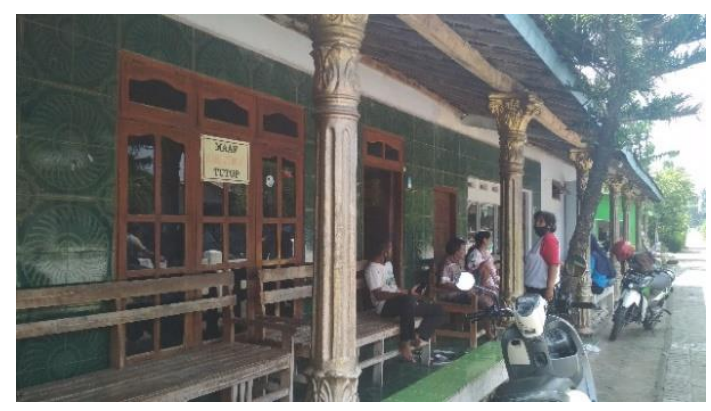

Gambar 2.

Penampakan bagian depan Panti Pijat Kendiku. Sumber : Dokumentasi Pribadi

Pijat biasanya dilakukan dengan menggunakan pelumas yang digunakan pada tubuh untuk memberikan efek licin dan hangat. Pelumas ini biasanya berupa minyak yang digunakan khusus untuk pijat, lotion tubuh, krim maupun balsem. Sedangkan di panti pijat Kendiku, menggunakan hand\&body lotion sebagai pelumas. Hal ini berfungsi untuk memperbaiki sirkulasi darah serta dapat membuat tubuh rileks.

Selama proses pemijatan, pasien akan berkomunikasi langsung dengan dukun pijat. Melalui percakapan tersebut, dukun pijat akan memberikan beberapa pantangan makanan kepada pasiennya. Pantangan makanan adalah pembatasan atau larangan kepada seseorang untuk mengkonsumsi makanan tertentu dalam waktu tertentu (Husaini, 2017). Selain melalui treatment dari luar berupa sentuhan fisik pemijatan, makanan juga berperan penting dalam membantu proses penyembuhan penyakit dari dalam tubuh. Pasien seringkali tidak menyadari bahwa kebiasaan makan dapat menjadi suatu sebab yang dapat memperparah penyakit. Sehingga dalam hal ini dukun pijat mencoba memberikan referensi yang berupa pantangan atau larangan makanan pada pasien. Pantangan ini berlaku untuk waktu tertentu sesuai dengan kondisi fisik pasien. Pantangan ini diberikan dengan supaya proses penyembuhan dapat lebih cepat.

Proses pemijatan berakhir tidak lebih dari 15 menit untuk masing-masing pasien. Pemijatan hanya dilakukan pada suatu titik tertentu pada tubuh pasien. Titik yang seringkali dipijat oleh dukun pijat panti Kendiku ini adalah area kaki dan telapak kaki, dimana di area tersebut terdapat banyak urat yang terhubung dengan bagian organ di dalam tubuh. Cara ini dianggap lebih efektif oleh dukun pijat panti Kendiku untuk memberikan treatment sesuai dengan penyakit yang dikeluhkan pasien. Selain itu, dengan durasi pemijatan yang singkat, sangat efektif untuk mempercepat antrian sehingga semua pasien yang datang bisa mendapatkan treatment yang diharapkan.

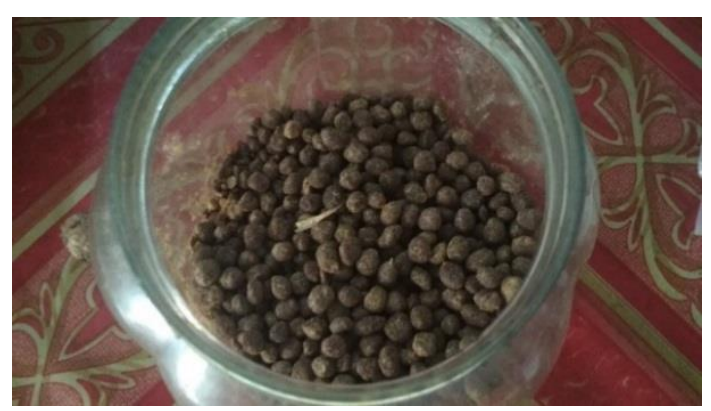

Gambar 3. Pil herbal Source: Dokumentasi Pribadi

Salah satu pembeda panti pijat Kendiku dengan pijat yang lainnya adalah penggunaan obat herbal atau jamu yang dipercaya berkhasiat untuk memelihara kesehatan tubuh. Rumah panti pijat ini menyediakan pil yang wajib untuk diminum oleh pasiennya setelah pemijatan. Pil ini terbuat dari empon-empon. Emponempon adalah sekelompok tanaman yang kaya akan senyawa seperti jahe, temulawak, kunyit, kencur, temu putih dan ditambah dengan bawang putih. Bahanbahan tersebut kemudian dihaluskan dan dicampur menjadi satu, kemudian dibentuk menjadi bulatanbulatan kecil dan dijemur, lalu akan didapatkan hasil 
yang sedemikian rupa. Pil ini dapat diminum oleh semua pasien tanpa dibedakan jenis penyakitnya. Hal ini karena pil tersebut hanya berfungsi untuk menambah daya tahan tubuh. Selain digunakan untuk membantu mempercepat penyembuhan, jamu tersebut juga berfungsi sebagai pencegahan datangnya suatu penyakit. Dengan imun yang kuat, penyakit akan menjauh dari tubuh seseorang.

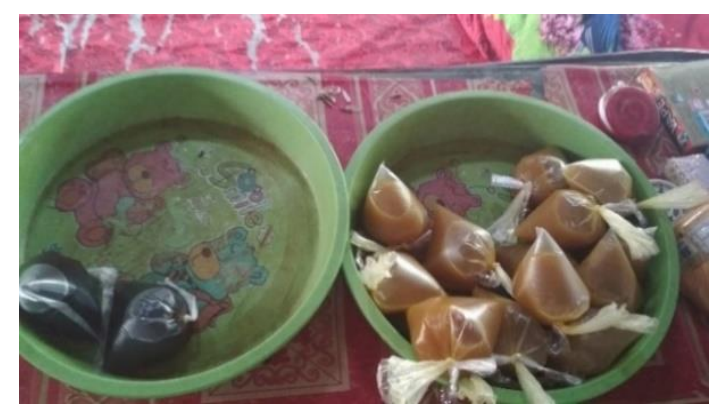

Gambar 4. Jamu herbal

Source: Dokumentasi Pribadi

Selain pil, rumah panti pijat Kendiku juga menyediakan dua macam jamu. Pertama, jamu dengan warna lebih gelap dan sering disebut jamu Pahitan. Disebut demikian karena rasanya paling pahit diantara jamu yang lainnya. Bahan-bahan yang dipakai dalam jamu ini adalah daun sambiloto ditambah dengan rempah-rempah temulawak dan temu ireng. Manfaat dari jamu Pahitan ini yakni mengatasi pegalpegal pada tubuh, serta untuk menambah nafsu makan. Lalu yang kedua, yaitu jamu berwarna coklat seperti jamu kebanyakan. Jamu ini terbuat dari emponempon seperti yang dibutuhkan pada pembuatan pil, namun tidak ditambah dengan bawang putih. Fungsi jamu ini juga tidak jauh berbeda dengan pil, yakni meningkatkan imunitas tubuh, melancarkan sistem metabolisme tubuh dan masih banyak lagi. Kedua jamu ini wajib diminum sesaat setelah pijat, tanpa membeda-bedakan jenis penyakit pasien. Biasanya, pasien akan disediakan satu gelas jamu untuk diminum di tempat, lalu dua bungkus jamu serta satu bungkus pil berisi lima butir untuk dibawa pulang. Apabila diperlukan, pasien dapat membeli lebih sesuai dengan kebutuhan.

Pijat Kendiku ini dapat mengatasi segala jenis penyakit termasuk penyakit berat, seperti stroke, diabetes, kencing manis, dan masih banyak lagi kecuali cedera, kecelakaan atau penyakit pada tulang. Rumah Panti Pijat Kendiku saat ini mematok tarif sebesar Rp. 60.000,- untuk semua jenis penyakit. Tarif ini sudah termasuk pijat beserta dengan pil dan tiga porsi jamu. Sedangkan apabila pasien menghendaki porsi ekstra jamu dan pil, tarif yang diberikan pun akan bertambah.

\section{Alasan Masyarakat Berobat ke Panti Pijat Kendiku}

Kebutuhan akan kesehatan tidak hanya sebagai kebutuhan individu, namun juga kebutuhan kolektif. Apabila seseorang sakit, maka orang terdekat baik keluarga ataupun kelompok akan mengusahakan berbagai cara untuk menyembuhkan penyakit tersebut agar penderita dapat menjalankan peran dan kewajibannya kembali di dalam masyarakat (Pelly dalam Sianipar, 1989). Oleh karena itu, banyak yang terlibat dalam pencarian metode penyembuhan untuk pasien, tentunya dengan mempertimbangkan berbagai hal.

Pemilihan metode pengobatan tentu menjadi perhatian sendiri bagi masyarakat. Mayoritas pasien Pijat Kendiku berpendapat bahwa faktor utama mereka memilih pengobatan alternatif ini adalah perasaan kecewa atau ketidakpuasan terhadap hasil pengobatan medis yang telah dijalani sebelumnya. Secara khusus, dapat dijelaskan antara lain pengobatan medis yang telah dijalani tidak membuahkan hasil, harga yang kurang terjangkau, risiko dan efek samping pengobatan medis dan sebagainya. Faktor-faktor tersebut menggambarkan kekecewaan masyarakat akan pengobatan medis modern, oleh karenanya masyarakat beralih ke pengobatan alternatif seperti pijat Kendiku. Pengobatan alternatif Kendiku ini masih sangat eksis di masyarakat. Masyarakat masih menganggap jika pengobatan tradisional jauh lebih membuahkan hasil serta minim efek samping. Selain itu, masyarakat desa percaya bahwa penyakit personalistik harus ditangani dengan pengobatan tradisional.

Berdasarkan hasil penelitian, alasan seseorang memilih panti pijat daripada pengobatan medis antara lain sebagai berikut.

\section{a) Mahalnya Biaya Pengobatan Medis}

Pengobatan secara medis sedikit banyak tentu memerlukan perawatan seperti halnya obat-obatan, bahkan tindakan operasi apabila penyakit yang diderita pasien adalah penyakit kronik yang membutuhkan penanganan lebih. Tindakan besar semacam operasi pastinya lebih mengeluarkan banyak uang daripada pengobatan tradisional. Penelitian menunjukkan bahwa sebagian orang lebih memilih pengobatan tradisional pijat daripada harus pergi ke dokter. Banyak dari pasien yang mengeluhkan bahwa pengobatan medis lebih mengeluarkan banyak uang namun hasil 
tidak sebanding. Lain halnya setelah pasien mencoba membandingkan dengan pengobatan pijat urat di rumah panti pijat Kendiku ini. Hasil dapat langsung dirasakan bagi pasien penyakit ringan seperti linu, keseleo dan sebagainya. Namun untuk penyakit serius seperti kencing manis, stroke, dan lain-lain memerlukan lebih banyak waktu untuk dapat merasakan hasil yang maksimal.

"Sakit prostat mbak, ini seharusnya operasi, tapi saya nggak berani. Mau coba disini yang lebih terjangkau. Saya rutin kesini, ada hasilnya. Ini sudah 2 bulan saya datang kesini" (wawancara Yono, April 2020).

Tarif yang berlaku untuk pasien panti pijat Kendiku ini termasuk terjangkau, hanya dengan biaya Rp. 60.000,- untuk sekali pijat. Harga tersebut sudah termasuk dengan jamu dan pil yang termasuk dalam rangkaian pengobatan khas Kendiku ini. Tentunya dengan tarif tersebut masyarakat dari kalangan bawah dapat menjangkaunya. Selain harga yang terjangkau, akses untuk menuju ke panti pijat Kendiku ini mudah dijangkau untuk didatangi masyarakat dari berbagai daerah.

\section{b) Risiko Pengobatan Medis}

Hasil penelitian menunjukkan bahwa alasan lain pasien memilih metode pengobatan pijat ini adalah 'ketakutan' terhadap efek samping yang ditimbulkan dari pengobatan secara medis. Operasi dan penggunaan obat-obat kimia medis dapat menimbulkan dampak lain disamping fungsi penyembuhan itu sendiri. Selain itu, pasien juga ditakutkan dengan hal-hal seperti kemungkinan sembuh yang kecil, terjadinya komplikasi dan efek samping lain yang mungkin timbul di kemudian hari.

"Saya kemarin dapat pasien mbak, kakinya nggak bisa buat jalan, kalau jalan itu sampai bungkuk gitu. Itu kan dia sakitnya kecetit, syaraf uratnya kejepit, nah kalau di dunia medis pengobatannya harus melalui operasi. Tapi ada efek sampingnya, yaitu lumpuh. Pasien saya ini nggak mau dengan resiko itu. Makanya dia mencoba berobat kesini" (wawancara Purnomo, April 2020).

Hal ini kemudian menjadi salah satu faktor penyebab pasien maupun keluarganya berusaha mencari cara atau solusi lain untuk mendapatkan penyembuhan. Banyak dari masyarakat yang kemudian mencoba pergi ke panti pijat Kendiku setelah mendengar informasi keberhasilan dari teman maupun saudara. Pasien dengan berbagai kondisi penyakit kronis biasanya akan diminta beberapa kali datang untuk dilakukan pemijatan agar hasil dapat terlihat maksimal.

\section{c) Hasil Pengobatan Medis yang Kurang} Memuaskan

Beberapa macam penyakit khususnya penyakit kronis membutuhkan lebih banyak waktu untuk penyembuhan, baik secara rawat inap maupun rawat jalan. Penelitian menunjukkan bahwa pengobatan medis yang telah dijalani sebelumnya tidak segera membuahkan hasil walaupun telah lama dilakukan pengobatan.

\section{"Saya ngantar suami saya mbak, beliau sakitnya darah tinggi. Sudah bolak-balik berobat ke rumah sakit. Belum berhasil. Coba disini kok justru berangsur-angsur membuahkan hasil" (wawancara Tatik, April 2020).}

Banyak dari pasien yang dijumpai peneliti berkata bahwa pengobatan medis belum membuahkan hasil bagi mereka. Namun setelah mencoba pijat urat Kendiku, pasien berangsur-angsur merasakan hasil ke arah positif. Terlebih lagi apabila pasien rutin datang untuk dilakukan pemijatan. Hasil perubahan ini dapat dilihat dari kondisi fisik yang terus membaik selama proses pengobatan.

d) Kepercayaan terhadap Penyakit Non Medis

Jika pada umumnya sebuah penyakit dapat dideteksi menggunakan ilmu medis, berbeda halnya dengan penyakit personalistik atau yang lebih dikenal sebagai penyakit non medis. Pada penyakit personalistik ini, sebuah penyakit dapat timbul akibat campur tangan 'agen' seperti makhluk halus, jin, setan, hantu dan roh-roh tertentu (Pelly dalam Sianipar, 1989). Hal mistis seperti guna-guna ini dipercaya sebagai suatu usaha seseorang yang menjadikan orang lain sebagai sasaran untuk mewujudkan keinginannya dengan cara menyakiti tubuh orang tersebut baik secara fisik maupun mental. Masyarakat percaya bahwa penyakit seperti ini tidak dapat disembuhkan secara medis, namun dapat disembuhkan dengan pengobatan tradisional seperti penanganan dukun. Bapak Purnomo selaku dukun pijat di panti Kendiku ini mengaku mampu menyembuhkan penyakit non medis atau personalistik. Pasien dan masyarakat sekitar pun percaya bahwa panti pijat Kendiku mampu menyembuhkan penyakit dengan sebab guna-guna tersebut. 


\section{Orientasi Masyarakat dalam Perilaku Pemilihan Pengobatan Pijat Kendiku}

Keadaaan sakit telah memengaruhi perilaku seseorang, antara lain perilaku dalam pencarian kesehatan (health seeking behavior), yang meliputi cara pencarian, pemilihan layanan kesehatan, dan akses terhadap layanan kesehatan tersebut (Husaini, 2017). Layanan kesehatan yang tersedia, baik pengobatan medis maupun tradisional masing-masing memiliki tingkat keberhasilan dan kegagalan. Sistem pengetahuan yang telah mandarah daging di dalam kebudayaan masyarakat kemudian mempengaruhi preferensi seseorang dalam memilih jenis pengobatan. Seiring dengan berjalannya waktu, sistem pengetahuan tersebut berkembang masuk melalui saluran-saluran media, kemudian informasi tersebut tersebar luas dan diterima untuk dijadikan pertimbangan dalam pemilihan layanan kesehatan.

Penelitian ini mengungkap bahwa banyak dari masyarakat lebih memilih dan percaya pada pengobatan pijat urat Kendiku. Adapun faktor utama seseorang dapat sembuh dengan metode tradisional yaitu karena pengobatan tradisional menggunakan obat herbal dan telah terbukti khasiatnya berdasarkan pengalaman yang sudah ada. Sejalan dengan hal ini, panti pijat Kendiku juga telah memproduksi dan menyediakan pil dan jamu herbal khusus untuk pasien yang datang berobat.

Selain itu, adanya rasa yakin atau percaya pada keberhasilan metode penyembuhan yang sedang digunakan. Rasa yakin inilah yang sangat memengaruhi cepat atau lambatnya seseorang dapat sembuh dari suatu penyakit. Efek psikologis yang dihasilkan dari rasa yakin ini kemudian memicu sistem kekebalan alami dalam tubuh yang dapat membantu proses pemulihan. Faktor lain adalah karena adanya rasa nyaman terhadap pengobatan tradisional, sebab seseorang tidak berada keadaan tertekan seperti di lingkungan rumah sakit. Pengobatan tradisional membebaskan keluarga pasien untuk mendampingi dan memberikan dukungan secara emosional sehingga pasien dapat memiliki rasa percaya diri untuk segera pulih (O'Neil, 2012). Tidak sedikit dari pasien yang berobat datang dengan didampingi keluarga atau orang terdekat. Hal ini membuktikan bahwa dengan adanya dukungan dari orang terdekat, mampu memberikan efek nyaman pada pasien sehingga menimbulkan dorongan dalam diri untuk segera sembuh.

Masyarakat dalam memilih pengobatan tidak hanya berdasarkan pada pengetahuan lokal dan budaya yang telah lama berkembang di dalam masyarakat. Menurut James C. Young, pemilihan tempat berobat ditentukan oleh 4 faktor (Young, 1994). Pertama, daya tarik (gravity). Ketertarikan seseorang terhadap suatu hal biasanya dapat berasal dari faktor luar. Ketertarikan tersebut disebabkan oleh adanya rasa penasaran dan kekaguman dari pengalaman orang lain yang telah terbukti sembuh setelah berobat. Daya tarik inilah yang kemudian mendorong seseorang untuk pergi ke panti pijat Kendiku.

Kedua, metode pengobatan yang sedang populer (popular). Masyarakat masa kini akan lebih tertarik pada hal-hal yang sedang populer dan ramai diperbincangkan. Hasil penelitian menunjukkan bahwa sebagian besar pasien mengetahui panti pijat Kendiku dari dua hal, yakni pengalaman orang lain dan media massa. Kedua hal tersebut sangat berperan dalam penyebaran informasi seputar pengobatan alternatif di masyarakat. Pengalaman pasien yang telah berhasil berobat di panti pijat Kendiku ini kemudian menjadi topik perbincangan dari mulut ke mulut hingga menyebar luas di masyarakat. Selain itu khasiat yang dirasakan setelah berobat kadangkala diposting oleh pasien di sosial media seperti Facebook dan lain-lain.

Ketiga, kepercayaan terhadap keberhasilan suatu pengobatan (faith). Adanya kepercayaan seseorang terhadap panti pijat Kendiku ini menjadi unsur yang tidak kalah penting. Faktor utama seperti pengobatan medis yang tidak membuahkan hasil semakin menambah tingkat kepercayaan masyarakat pada pengobatan ini. Ditambah dengan banyaknya pasien yang berangsur-angsur sembuh setelah menjalani pengobatan. Hal ini kemudian memengaruhi kepercayaan calon pasien yang datang terhadap keberhasilan pengobatan tradisional ini. Selain itu, kepercayaan bahwa pengobatan tradisional satusatunya yang mampu mengatasi penyakit personalistik juga menjadi alasan kuat calon pasien.

Keempat, kemudahan (accessibility). Faktor kemudahan ini meliputi biaya, akses kendaraan, dan tersedianya fasilitas pelayanan sesuai kebutuhan (Leavitt, 1992). Majunya ilmu pengetahuan dan teknologi membawa konsekuensi tersendiri, yakni perlunya biaya yang tinggi untuk dapat mengakses layanan pengobatan medis yang canggih dan modern (Setyawan, 2018). Sejalan dengan hal itu, melonjaknya harga obat-obatan kimia juga memberikan peluang masyarakat untuk kembali memanfaatkan pengobatan alternatif (Putro, 2018). Kaitannya dengan hal tersebut, Pijat Kendiku ini memasang tarif harga yang terjangkau untuk mendapatkan hasil yang diharapkan. Akses jalan yang 
harus ditempuh pasien untuk menuju panti Kendiku ini juga terbilang mudah. Fasilitas lahan parkir juga sudah tersedia bagi pasien. Selain itu, keberadaan panti pijat ini dapat dijangkau oleh masyarakat desa yang masih menganggap bahwa penyakit personalistik atau non medis harus disembuhkan dengan pengobatan non medis pula. Pijat urat Kendiku memberikan pelayanan terhadap jenis-jenis penyakit personalistik sesuai keluhan dan kebutuhan pasien.

\section{KESIMPULAN}

$\mathrm{P}$ ijat merupakan suatu metode dalam memelihara kesehatan yang masih dicintai di kalangan masyarakat. Seperti halnya di Desa Cengkok Kecamatan Ngronggot Kabupaten Nganjuk, terdapat rumah panti pijat Kendiku yang mampu menarik banyak pasien untuk berobat tiap harinya. Panti ini berpotensi mengeksiskan kembali budaya budaya yang ada. Hal ini dapat dilihat dari penggabungan antara metode pijat dan penggunaan tanaman herbal sebagai bahan baku jamu di panti pijat sehingga hasil penyembuhan pada pasien dapat lebih cepat terlihat. Hal ini berarti bahwa panti pijat Kendiku mencoba untuk melestarikan budaya yang telah lama ada di masyarakat dengan cara dan kondisi yang sesuai di masyarakat saat ini (Purwasih et al., 2019). Rumah panti pijat ini menggunakan metode yang berbeda dengan pijat pada umumnya, yakni durasi waktu pemijatan yang singkat untuk segala jenis penyakit maupun keluhan, adanya pantanganpantangan makanan yang diberikan, serangkaian pengobatan seperti jamu dan pil, serta tarif yang dapat dikatakan terjangkau.

Banyak orang yang sudah percaya dengan pengobatan di panti pijat Kendiku, terbukti dengan banyaknya orang yang datang berobat tiap harinya. Tidak sedikit pasien yang datang merupakan pasien yang tidak berhasil dalam pengobatan medis maupun pengobatan lain sebelumnya. Banyak pula pasien yang hanya mengeluhkan pegal dan nyeri otot seperti pasien pijat pada umumnya. Panti Pijat Kendiku dalam hal ini melayani pasien baik dari keluhan ringan hingga berat, kecuali usia bayi dan anak-anak. Selain dari pasien tetap yang rutin berobat, pasien-pasien baru yang datang dari berbagai daerah juga mencoba untuk berobat ke panti pijat ini dengan harapan dapat diberikan kesembuhan terhadap penyakit yang dideritanya. Pasien-pasien yang baru akan mencoba pelayanan Pijat Kendiku biasanya mendapatkan informasi dari teman, tetangga maupun sanak saudaranya yang pernah mencoba berobat ke Panti ini. Selain itu, terdapat berbagai alasan masyarakat lebih memilih pengobatan tradisional ini daripada pengobatan medis, antara lain karena adanya peluang resiko yang ditimbulkan pengobatan medis, hasil pengobatan medis yang kurang memuaskan, mahal serta adanya kepercayaan terhadap penyakit-penyakit personalistik.

Segala jenis pengobatan baik medis maupun alternatif memiliki tingkat keberhasilan dan kegagalannya masing-masing. Namun, pengobatan tradisional seperti pijat Kendiku dalam hal ini memiliki nilai lebih, yakni bahan obat dan jamu herbal yang digunakan serta lingkungan yang mendukung terjalinnya ikatan emosional antara pasien dengan keluarga pendamping. Sejalan dengan pemikiran James $C$. Young bahwa terdapat 4 faktor yang sesuai pada pasien pijat Kendiku dalam memilih jenis pengobatan, antara lain daya tarik (gravity), pengobatan yang sedang popoler di masyarakat (popular), kepercayaan (faith) dan kemudahan (accessibility).

\section{E. UCAPAN TERIMA KASIH}

$\mathrm{T}$ erima kasih penulis sampaikan kepada Universitas Negeri Malang atas kesempatan untuk menulis artikel ini sebagai hasil penelitian skripsi. Demikian halnya dengan pihak rumah panti pijat Kendiku yang telah bersedia memberi kesempatan kepada penulis untuk mengumpulkan data yang dibutuhkan selama penelitian.

\section{DAFTAR PUSTAKA}

Aditama, T. Y. (2014). Jamu dan Kesehatan.

Ardani, I. (2013). Eksistensi Dukun Dalam Era Dokter Spesialis. Lakon : Jurnal Kajian Sastra Dan Budaya, 2(1), 21. https://doi.org/10.20473/lakon.v2i1.1913

Ayunita, T. (2016). Pengobatan Pijat Anak dengan Media Sikil Kidang: Kajian tentang Praktik Etnomedisin pada Masyarakat Desa Kesugihan Kecamatan Kesugihan Kabupaten Cilacap. UNIVERSITAS NEGERI SEMARANG.

Cresswell, J. W. (2007). Qualitative Inquiry and Research Design: Choosing Among Five Traditions. In Western Journal of Nursing Research (Vol. 21, Issue 1, pp. 103-105).

Huda, M. D. (2015). Peran Dukun terhadap Perkembangan Peradaban Budaya Masyarakat Jawa. 4. 
Husaini. (2017). Buku ajar antropologi sosial kesehatan.

Jennifer, H., \& Saptutyningsih, E. (2015). Preferensi Individu terhadap Pengobatan Tradisional di Indonesia. 16(April).

Leavitt, R. L. (1992). Disability and Rehabilitation in Rural Jamaica: An Ethnographic Study. Associated University Presses.

https://books.google.co.id/books?id=kX3D7OCFfaQC\&pg=PA233\&lpg=PA233\&dq=JAMES+YOUNG+ 1980+gravity,+faith,+accessibility\&source=bl\&ots=Bf9uxjl0ED\&sig=ACfU3U3HwbJexmLx0aa_Uvd12F OAVc6BOQ\&hl=en\&sa=X\&ved=2ahUKEwiwh mlia7rAhULb30KHeVOCuQQ6AEwAHoECAoQAQ\#v=onepage\&

Moeis, S. (2009). Pembentukan kebudayaan nasional Indonesia. Makalah. UPI Bandung.

Moordiningsih. (2009). Terapi Pijat Oriental: Budaya Harmonisasi Fisik dan Psikis. BioPsychology Improving The Quality of Life, 1-5. http://eprints.ums.ac.id/33027/

Nuari, K. S. (2016). Pengambilan Keputusan Pasien dalam Memilih Pengobatan Pijat Bakaran Menyan Mbah Parsinah di Desa Dawuhan, Banyumas. UNIVERSITAS NEGERI SEMARANG.

O'Neil, D. (2012). Medical Anthropology: How Illness is Traditionally Perceived and Cured Around the World. 117. https://www2.palomar.edu/anthro/medical/default.htm

Prakoso, S. B. (2015). Efektivitas Pelayanan Kesehatan BPJS Di Puskesmas Kecamatan Batang. Economics Development Analysis Journal, 4(1), 73-81. https://doi.org/10.15294/edaj.v4i1.14805

Purwasih, J. H. G., Wijaya, M., \& Kartono, D. T. (2019). Strategi Bertahan Hidup Perajin Gerabah Tradisional. Jurnal Antropologi: Isu-Isu Sosial Budaya, 21(2), 159. https://doi.org/10.25077/jantro.v21.n2.p159167.2019

Putri, N. E. (2014). Efektivitas Penerapan Jaminan Kesehatan Nasional Melalui BPJS dalam Pelayanan Kesehatan Masyarakat Miskin di Kota Padang. Tingkap, X(2), 175-189. https://doi.org/10.1016/S16972600(13)70010-3

Putro, B. D. (2018). Persepsi dan Perilaku Pengobatan Tradisional Sebagai Alternatif Upaya Mereduksi Penyakit Tidak Menular. Sunari Penjor: Journal of Anthropology, 2(2), 102-109. https://ojs.unud.ac.id/index.php/penjor/article/view/46134

Rarasati, D. H. (2018). Dampak Kenaikan Tarif BPJS Kesehatan terhadap Pelayanan Kesehatan di Kota Malang. Jurnal Politik Muda, 1-13.

S. Supardi, S. Jamal, A. M. L. (2003). Beberapa Faktor yang Berhubungan dengan Penggunaan Obat Tradisional dalam Pengobatan Sendiri di Indonesia. Bul. Penel. Kesehatan, 31(3), 25-32.

Sativa, R. L. (2016). Januari: Kisah Pilu Allya yang Meninggal Usai Terapi di Klinik Chiropractor. Detikhealth.Com. https://health.detik.com/berita-detikhealth/d-3374582/januari-kisah-pilu-allya-yang-meninggal-usaiterapi-di-klinik-chiropractor

Setyawan, F. E. B. (2018). Sistem Pembiayaan Kesehatan. 2 No.4, 57-70.

Setyoningsih, A., \& Artaria, M. D. (2016). Pemilihan penyembuhan penyakit melalui pengobatan tradisional non medis atau medis. Masyarakat, Kebudayaan Dan Politik, 29, 44-56.

Sianipar, T. (1989). Dukun, Mantra dan Kepercayaan Masyarakat.

Sliz, D., Smith, A., Wiebking, C., Northoff, G., \& Hayley, S. (2012). Neural correlates of a single-session massage treatment. January, 77-87. https://doi.org/10.1007/s11682-011-9146-z

Suharyanto, A. (2015). Eksistensi Paranormal dan Penyembuh Alternatif dalam Kehidupan Masyarakat Medan. Anthropos: Jurnal Antropologi Sosial Dan Budaya (Journal of Social and Cultural Anthropology), 1(2), 196-201. https://doi.org/10.24114/ANTRO.V112.6244

Ticoalu, S. S. (2013). Tanggung Jawab Pemerintah dalam Memberikan Pelayanan Kesehatan Terhadap Masyarakat. 26(4), 1-37.

Tjandrawinata, R. (2016). Industri 4.0: revolusi industri abad ini dan pengaruhnya pada bidang kesehatan dan bioteknologi. February. https://doi.org/10.5281/zenodo.49404

Triratnawati, A. (2010). Pengobatan tradisional, upaya meminimalkan biaya kesehatan masyarakat desa di Jawa. Jurnal Manajemen Pelayanan Kesehatan, 13(2), 69-73. https://journal.ugm.ac.id/jmpk/article/viewFile/2598/2329

Whi, M. (n.d.). Asuhan Keperawatan Jiwa pada Ny. S dengan Gangguan Persepsi Sensori: Halusinasi Pendengaran di RSJD Dr. Amino Gondohutomo Semarang. 32, ص ص 117.

Womack, M. (2010). The Anthropology of Health and Healing. Altamira Press.

Young, J. C. (1994). Medical Choice in a Mexican Village. Waveland Press. https://books.google.co.id/books/about/Medical_Choice_in_a_Mexican_Village.html?id=Hy0157NuQ0 YC\&redir_esc=y

Zulaikha, S., Hadi, N., \& Purwasih, J. H. G. (2021). Melemahnya Budaya Jamu Cekok di Kelurahan Pare. Jurnal Antropologi: Isu-Isu Sosial Budaya, 01(June), 47-57. 